\title{
Muerte, fantasmas y locura en dos narraciones de Bernardo Couto Castillo
}

\author{
(1) Ariela Érica Schnirmajer \\ Universidad de Buenos Aires-Universidad Nacional Arturo Jauretche- \\ Universidad Nacional de San Martín, Argentina
}

\begin{abstract}
Resumen
En este artículo me propongo explorar las narraciones "Una obsesión" (1901) y "Celos póstumos" (1898)de Bernardo Couto Castillo publicadas en Revista Moderna, en su primera época(1898-1903). La figura del escritor cobra relevancia ya que no solo se trata de uno de los iniciadores de la Revista Moderna, sino uno de los escritores más representativos de la veta decadentista en dicha publicación hasta 1901, fecha de su muerte. Postulo que, en ambos relatos, la configuración del tríptico narrador alucinado (Colombi, 2013:232), mujer y muerte se transforma en un dispositivo narrativo/descriptivo abierto a la indagación de otras realidades como la muerte y la locura. Este dispositivo permite delinear sensaciones y percepciones que serebelan contra la razón y dan entrada al dominio de lo irracional a través del fantasy(Jackson 1986). Estas operaciones se realizan por medio de la apropiación (Chartier, 1996:52) y combinación selectiva de algunas temáticas y procedimientos de Edgar Allan Poe en conexión con ciertas imágenes de la pintura prerrafaelista en "Una Obsesión", mientras que en "Celos póstumos" el autor recurre al tópico barroco de la vanitas para lograr tal efecto. Las búsquedas de Couto Castillo chocaban con el México porfirista que postulaba una modernización asociada al mercantilismo, en donde el arte parecía un trabajo inútil e improductivo, a menos que se ejerciera en beneficio de los intereses del Estado.
\end{abstract}

\section{Death, ghosts and madness in two narrations of Bernardo Couto Castillo}

\begin{abstract}
In this article I propose to explore the narrations "Una obsession" (1901) and "Celos póstumos" (1898), by Bernardo Couto Castillo, published in Revista Moderna in its first time (1898-1903). The figure of the writer becomes relevant since it is not just about one of the iniciators of Modern Magazine, but also one of the most representative writers of the decadent vein in that publication until 1901, date of his death. I postulate in both stories, the configuration of the trippy hallucinated narrator (Colombi, 2013:232), women and death become a descriptive narrative device, open to the enquiry of other realities, such as death and madness. This device allows to delineate sensations and
\end{abstract}

Palabras clave

Bernardo Couto Castillo Revista Moderna narrador alucinado mujer muerte

Keywords

Bernardo Couto Castillo Revista Moderna hallucinatedstoryteller woman death 
perceptions that are revealed against the reason and gives entrance to the domain of the irrational through the fantasy. These operations are performed by means of the appropriation (Chartier, 1996:52) and selective combination of some thematics and procedures of Edgar Allan Poe in conection with certain images of pre-Raphaelite painting in "An obsession"; while in "Posthumous jealousy" the author resorts to the baroque topical of vanitas to achieve such an effect. Couto Castillo's searches clashed with the Mexican porfirista that postulated a modernization associated with mercantilism, where the art seemed like a useless and unproductive job, unless it is exercised in the interest of the state.

\section{Morte, fantasmas e loucura em duas narrações de Bernardo Couto Castillo}

\section{Resumo}

\section{Palavras-chave}

Bernardo Couto Castillo Revista Moderna narrador alucinado mulher morte
Em este artigo de pesquisa procuro explorar as narrações "Una obsesión" (1901) e "Celos póstumos" (1898) de Bernardo Couto Castillo publicadas em Revista Moderna, em seus primeiros tempos (1898-1903). Sua figura de escritor tem muita importância já que não só é um dos iniciadores da Revista Moderna, mas também um dos escritores mais representativos da linha decadentista dessa publicação até 1901, data de sua morte. Postulo que em duas narrações, a configuração da tríade do narrador alucinado (Colombi, 2013:232), mulher e morte se transforma em um dispositivo narrativo/ descritivo aberto à indagação de outras realidades como a morte e a loucura. Este dispositivo permite delinear sensações e percepções que se rebelam contra o raciocínio e possibilitam o acesso ao domínio do irracional através do fantasy. Em "Una obsesión", estes procedimentos se realizam por meio da apropiação e combinação seletiva de alguns temas e procedimentos de Edgar Allan Poe em relação com determinadas imagens da pintura prerrafaelista, enquanto em "Celos póstumos" o autor recupera o tópico barroco do vanitas para conseguir o mesmo efeito. Os interesses estéticos de Couto Castillo colidiam com o México porfirista que perseguía uma modernização associada ao mercantilismo, onde o arte parecia então um trabalho inútil e improdutivo, a menos que tivesse alguma utilidade em benefício dos interesses do Estado.

Revista Moderna (1898-1903) en México nace vinculada al deseo de provocar a los sectores más conservadores de la sociedad. Se transforma en el vehículo del modernismo, a través de la veta decadente, en rebeldía contra las formas anteriores de la literatura, ancladas en el realismo y el nacionalismo, y contra la sociedad burguesa. En sus temáticas se afanaron por encontrar los goces fuera de la realidad, forjando un mundo lleno de deleites malsanos, en estrecho diálogo con las búsquedas del simbolismo francés y las narraciones terroríficas de Edgar Allan Poe. Éstas chocaban con el México porfirista que postulaba una modernización asociada al mercantilismo, en donde el arte parecía un trabajo inútil e improductivo, a menos que se ejerciera en beneficio de los intereses del Estado.

Bernardo Couto Castillo no solo fue uno de los iniciadores de la Revista Moderna sino uno de los escritores más representativos de la tendencia decadentista en dicha publicación hasta 1901, fecha de su muerte, con apenas veintiún años. Zavala Díaz argumenta que Couto Castillo creó un mundo textual, habitado de figuras atormentadas, a través del cual buscó organizar la realidad a partir de métodos alternativos a los positivistas, tales como la intuición, el uso de excitantes, la locura, las alucinaciones y la violencia, todas vías "irracionales" en las que sustenta su visión estética de la vida (Zavala Díaz, 2012:132). 
Una caracterización de José Ricardo Chaves sintetiza con claridad las variantes decadentes. Según el investigador, ésta presenta diferentes matices, puede ser eróticatransgresora, mística, esotérica, drogofílica; estos elementos aparecen por separado o en variadas combinaciones. También, se manifiesta bajo la modalidad esteticista o nihilista (Chaves, 2013:151). El universo coutiano se inscribe en un nihilismo perturbador cuyo tema recurrente es la muerte.

En estrecha relación con la importancia de la muerte en la obra de Bernardo Couto Castillo,Coral Velázquez Alvarado en su "Estudio preliminar" a la Obra reunida del autor, distingue distintas inflexiones en su producción: un período vinculado a la composición realista, previa a su viaje a Europa en 1894; luego, a su regreso en 1896, una vena poética, asociada al poema en prosa. Posteriormente, con la publicación de Asfódelos en 1897, las narraciones abordan la línea de las alucinaciones, pesadillas y apariciones como parte de sus temáticas. Estas ingresan en relatos en donde el miedo a la muerte y la presencia de seres del más allá cobran centralidad (Velázquez Alvarado, 2014: 131-132).

En este trabajo nos concentraremos en la última etapa coutiana, en la que el escritor profundiza "en la descripción de sensaciones y en el desarrollo de personajes alienados de la sociedad" (Velázquez Alvarado 2014:132). En ese marco, proponemos que el tríptico que integran el narrador alucinado (Colombi, 2013), la mujer y la muerte en dos relatos publicados en Revista Moderna, "Una obsesión" y "Celos póstumos", se configura como un dispositivo narrativo/descriptivo en el que se indaga en otras realidades que se rebelan contra la razón y dan entrada al dominio de lo irracional a través del fantasy. Respecto del narrador alucinado, seguimos a Beatriz Colombi, quien sostiene que

La clave es la impostación de una voz delirante que solo una conciencia atenta y matemática puede producir y conducir. Una de las marcas más constantes de la estética moderna, y uno de los legados que vía Darío se transmite a la tradición literaria local. (2013:232)

En relación con la afirmación anterior, indagamos en los mecanismos constructivos empleados para configurar a un narrador que ha perdido toda certeza y estabilidad. En esa línea, postulamos que la apropiación (Chartier, 1996) y combinación selectiva que efectúa Couto Castillo de algunas temáticas y procedimientos de Edgar Allan Poe en conexión con ciertas imágenes de la pintura prerrafaelista generan la figura del narrador alucinado en "Una Obsesión"; mientras que en "Celos póstúmos", para lograr tal efecto, el autor recurre al tópico barroco del memento mori vinculado al vanitas. Para la delimitación del concepto de apropiación, es pertinente el abordaje de Chartier, quien señala que esta noción apunta a

una historia social de usos e interpretaciones, relacionados con sus determinaciones fundamentales e inscritos en las prácticas específicas que los producen. Prestar así atención a las condiciones y a los procesos que, muy concretamente, llevan las operaciones de construcción de sentido (en la relación de lectura pero también en muchas otras) es reconocer, en contra de la antigua historia intelectual, que ni las inteligencias ni las ideas son desencarnadas y, contra los pensamientos de lo universal, que las categorías dadas como invariables, ya sean filosóficas o fenomenológicas, deben constituirse en la discontinuidad de las trayectorias históricas. (1996: 53) ${ }^{1}$

En ambas narraciones, lo femenino entraña deseo, temor y culpa, aspectos que también se inscriben en una tradición cultural y literaria en la que Couto Castillo abreva y con la cual dialoga. Respecto de esta genealogía, es pertinente recordar la explicación de Jean Pierrot en L'imaginaire décadent 1880-1900 sobre el contexto de conformación de la polarización de la mujer ángel versus la mujer fatal.
1. Caracterizamos algunas producciones del primer número de Revista Moderna y su sintonía con ciertas búsquedas coutianas. La página uno es ilustrativa de sus concepciones poéticas. Incluye dos poemas: "Hostias Negras VI" de José Juan Tablada y “El Arte”, traducción de Théophile Gautier por Balbino Dávalos. La composición encierra parte de los ideales estéticos de estos poetas: el parnasianismo, desarrollado en Francia, suponía la preeminencia de la forma y concebía al poeta como artesano de la palabra. Revista Moderna apostó a la traducción de poetas franceses, incluyó a decadentes como Baudelaire, Verlaine, Mallarmé y Moreas, buscando una renovación de la poesía que superara las barreras nacionales y los marcos realistas. En este número también se incluye un grabado de Julio Ruelas "Centauro en agonía”, que anuncia la temática de la revista. Ruelas estableció un fuerte vínculo creativo con Couto Castillo. En el grabado, se puede asimilar el joven semblante del centauro al del pintor; las extremidades pertenecen a un centauro que yace moribundo, posee una herida abierta en el pecho, símbolo de la dualidad hombre-bestia que representará el ánimo espiritual del modernismo de la Revista Moderna y muestra los deseos de abrirse a representaciones que escapan a los moldes realistas. 
El investigador refiere que la época decadente impulsa, antes que Sigmund Freud desarrolle su idea fundamental de la distinción entre lo consciente y lo inconsciente, la hipótesis de la existencia del inconsciente, es decir, de una actividad mental del espíritu humano. Karl Edouard von Hartmann, en Filosofí del inconsciente (1868) despliega una teoría del mismo como una fuerza impersonal y general que conduce la existencia de todas las especies vivientes; el estudio propone una dimensión más biológica que psicológica. Esta fuerza obliga a los individuos a obrar a pesar de sí mismos por los mecanismos del instinto. En la teoría del amor que desarrolla von Hartmann reconoce el rol de inconsciente, sin embargo, considera que tienen mayor peso los instintos sexuales (1977: 151-180).

Los secretos profundos del inconsciente, el psiquismo y los fenómenos excepcionales son trabajados en el interior de las obras literarias como parte de la naturaleza misma de la sensibilidad decadente. Los decadentes descubrieron la sexualidad, pero en gran parte para refutarla, o al menos para rebatir sus manifestaciones normales. Recalcan el anti naturalismo, que entraña un antifeminismo, porque la mujer simboliza la naturaleza. En este punto, Pierrot reconoce la gravitación de Baudelaire y Schopenhauer en estas representaciones. La mujer se ve reducida a su cuerpo, y el universo de la vida espiritual le es absolutamente inaccesible. La sexualidad se liga a la culpa y se desarrolla el mito de la "Mujer Fatal", que subraya el carácter destructivo de la pasión y triunfa la imagen de la mujer lujuriosa y cruel. Simétricamente, la mujer ideal y angélica será representada por una serie de figuras femeninas aureoladas de espiritualidad. Atendiendo a las consideraciones anteriores, nos interesa indagar en la función que la mujer ángel y la mujer fatal poseen en el tríptico narrador-mujer-muerte antes señalado.

\section{El demonio de la perversidad}

Los asesinos célebres, los seres horripilantes, los diabólicos me seducían. Soñaba con personajes como los de Poe, como los de Barbeyd'Aurevilly; (...) soñaba con los seres demoníacos que Baudelaire hubiera podido crear (1897:186)

"Cuentos criminales. Blanco y rojo", Bernardo Couto Castillo

"Una obsesión" formó parte de Asfódelos y, en el marco de los doce relatos que conforman la colección, contiene a la primera suicida de la serie. Posteriormente se publicó en mayo de 1901 en Revista Moderna, con ilustraciones de Julio Ruelas (18701907), quien fuera el creador de la fisonomía de la revista. ${ }^{2}$ Sus tendencias artísticas lo ponen de inmediato en contacto con los jóvenes poetas y narradores decadentistas, con los que comparte una visión desesperanzada del mundo, en donde el sufrimiento y el dolor dominan su paleta.

El epígrafe que encabeza esta sección forma parte de la confesión de Alfonso Castro, protagonista de "Blanco y Rojo" de Couto Castillo, quien después de asesinar a su amante, enumera sus preferencias literarias. "Una obsesión" sigue este linaje ya que el protagonista se inscribe en la galería de personajes alucinados de Poe. El cuento se sostiene en una carta encontrada en el fondo de un cajón de un mueble Luis XV recientemente adquirido por un narrador inicial, quien presenta la epístola para después desaparecer por completo. Como señala Coral Velázquez Alvarado, "la estrategia de enmarcar la narración genera que el narrador y el lector compartan la función de destinatarios de un texto escrito en el pasado, que cobra voz en primera persona" (2014:135).De esa manera, explica la investigadora, Couto crea un vínculo entre el narrador o nuevo dueño del mueble, el "querido amigo", destinatario del escrito, y el propio lector del relato. Como se señaló, la carta ha sido encontrada en el fondo de un cajón. Al respecto, Gastón Bachelard señala que ante la apertura de un cofre 
(...) todo es novedad, sorpresa, desconocido. Lo de fuera ya no significa nada. E incluso

(...) las dimensiones del volumen ya no tienen sentido porque acaba de abrirse otra

dimensión: la dimensión de intimidad. (Bachelard, 1992:120)

En sintonía con la cita de Bachelard, en el interior de la carta encontrada, por medio de un racconto, el personaje masculino practica la introspección y da voz al espacio de lo privado. Sin embargo, las dudas acerca de la credibilidad de su percepción de los hechos surgen rápidamente: "Lo que te escribo va a extrañarte profundamente; pero no tienes una idea del estado de excitación y de pesar en que me encuentro" (159). En el relato, se cuenta la historia de un hombre que, a causa de su egoísmo y su "perversa curiosidad", provoca el suicidio de su amada. En consecuencia, experimenta una culpa que lo conduce a un estado alucinatorio, en el cual cree sentir el retorno amenazante de la muerta.

Rosemary Jackson define el fantasy como un modo que asume formas genéricas diferentes. La investigadora señala que éste, tal como surgió en el siglo xix, tuvo una íntima relación con la novela, un género al que socavó. Se trata de una modalidad que

afirma que es real lo que está contando -para lo cual se apoya en todas las convenciones de la ficción realista- y entonces procede a romper ese supuesto realismo, al introducir lo que es manifiestamente irreal (...). El narrador no entiende lo que está pasando, ni su interpretación (...) constantemente se cuestiona la naturaleza de lo que ve y registra como «real»" (1986:31-32).

La inestabilidad narrativa constituye el centro del fantasy como modo (1986: 32). ${ }^{3}$ Según esta definición, la ruptura de la isotopía realista y la poca fiabilidad del narrador de "Una obsesión" nos permiten considerar su inclusión dentro de esta modalidad. Avancemos en esta línea.

En otros tiempos, el narrador había llevado una vida desordenada, y ahora padece la ausencia de su amada, con quien había compartido un feliz vínculo amoroso durante dos años, alejado de toda conducta libertina previa. La pérdida de la amada ha generado que su vida y su mente se encuentren desequilibradas. En la descripción de los momentos de dicha compartidos, el personaje femenino se ajusta al prototipo de la mujer frágil; toda la delineación de obediencia y sumisión confirma este perfil y se remata con la comparación física femenina con la virgen prerrafaelista. La figura de la mujer frágil fue tomada de los prerrafaelistas, movimiento artístico que surgió en Inglaterra a mediados del siglo xix, constituido por John Everett Millais, William Holman Hunt y Dante Gabriel Rossetti, quienes tenían como objetivo luchar contra el academicismo, la sociedad industrial y la estructura victoriana.

Un falso amigo del narrador, Carlos X, "miserable Yago" (159), desencadenó el conflictoal revelarle a Julia, la mujer frágil, el pasado turbulento del narrador, lo que provocó sus encendidos reproches. Carlos X oficia de "demonio de la perversidad", señalando el guiño intertextual con el cuento homónimo de Poe. En la ficción del norteamericano, el demonio de la perversidad se pone en acción cuando se siente una "invencible tendencia a hacer el mal por el mal mismo" (1990:187), "simplemente porque sentimos que no deberiamos hacerlo" (1990:189); esto desemboca en el crimen, el posterior sentimiento de culpa y la auto confesión del narrador protagonista. En "Una obsesión" el demonio de la perversidad involucra la delación y la traición del amigo. Ante las ironías y desaires del narrador a las recriminaciones femeninas para contraer nupcias, la mujer se venga al colocar el cañón de su revólver en la frente $\mathrm{y}$, en presencia de la "curiosidad perversa"del narrador, se suicida con un tiro en la sien. En ese instante del relato, se produce una sustitución: Julia se transforma en la mujer fatal a causa del odio y se la llama "leona iracunda", que "solo quiere arañar y destruir" (160), privándola de todo atisbo de racionalidad.
3. Podemos relacionar la definición de Rosemary Jackson del fantasy con la explicación que brinda Jean Pierrot sobre la aparición del cuento fantástico en Francia durante la segunda mitad del siglo xix en el capítulo "Avatares del fantástico". El investigador refiere que la generación decadente, desilusionada por la realidad contemporánea, buscó un refugio en lo imaginario. Para Pierrot, el cuento fantástico nace en Francia en la época romántica, bajo el influjo de la obra de Hoffmann, con la función de hacer aparecer, de manera verosímil, hechos sobrenaturales o sin sentido en la realidad cotidiana. De este modo, surge, paulatinamente, una literatura fantástica de características físico-patológicas, en la que las fantasías se identifican como fantasmas. A su vez desparece, en forma progresiva, el fantástico demoníaco, para insistir en la descripción de estados psicológicos excepcionales. El cuento fantástico posee cada vez una estructura más rigurosa y conduce de manera más eficaz la sensibilidad del lector. 
4. José Ricardo Chaves señala que la contemplación de la amada muerta, ya sea por el asesinato o por el suicidio, es una situación recurrenteen la narrativa de Couto (2013:152)

5. E. A. Poe. The Philosophy of Composition [en línea]. "La muerte de una mujer hermosa, entonces, sin disputa de ninguna clase, es el tema más poético del mundo, $y$ queda igualmente fuera de duda que la voz más apta para desarrollar ese tema es, precisamente, la del amante privado de su ser querido. http://www.eapoe.org/works/ essays/philcomp.htm [Consultado: 6 de diciembre de 2019].

6. Por la precisión atenta en la evocación de estados psicológicos marginales, como los relativos al miedo, las angustias, las obsesione mórbidas, la psicología del crimen y de la locura, la obra de Poe, largamente difundida a partir de los primeros años del Segundo Imperio, jugó un rol considerable para favorecer esta evolución. En Francia fue la obra de Guy de Maupassant donde mejor se desarrollaron estas tendencias. En este trabajo abordamos las formas de apropiación de Couto Castillo de algunas técnicas y temáticas de Poe. En relación con Maupassant, este fue leído y admirado por el mexicano. Vicente Quirarte analiza el ensayo de Tablada "El Monstruo", publicado en la Revista Moderna en abril de 1899 y dedicado Couto Castillo (2001:3031). En el ensayo, Tablada efectúa un recorrido a través de las criaturas que han provocado los terrores del hombre para comprobar su inexistencia. Concluye con el siguiente señalamiento: "Ya no hay monstruos en la vida moderna, en la vida plástica cuando menos; pero en el mundo moral existimos larvas de monstruos, tendremos alas cuando sobrevenga el superhombre, en entre tanto nuestro estado medio, nuestra crisálida será algo así como El Horla de Maupassant" (1899: 102). Quirarte señala que el texto citado de Maupassant se publicó en 1886 y cinco años después el autor se suicidó. El crítico considera que tanto El Horla como las narraciones de Poe ponen el foco en los terrores internos, temática central en la narrativa de Couto Castillo.
Si bien el narrador le teme a esta fémina animalizada, tal figuración se puede vincular con una serie de representaciones pictóricas de la época en las que se asociaba a las mujeres con un grado de menor evolución biológica. La imagen de la mujer como una criatura bella pero sin evolucionar permitía establecer el mismo tipo de comparación que entre un hombre blanco y uno negro o cualquier otro indígena de las tierras colonizadas por los europeos. Bram Dijkstra remite a cuadros de mujeres acompañadas de faunos u otras criaturas de manera deliberada animalizadas con poses de simios o debidamente caricaturizadas, que permitían una lectura doble y negativa. El hecho de que las mujeres fueran compañeras de dichas criaturas era la constatación de la naturaleza estática de la femineidad y, al mismo tiempo, se presentaba el bestialismo y atraso de estas razas colocándolas en posición inferior a la blanca y occidental y presentándolas como peligrosas y agresivas.

En este sentido, en "Una obsesión", progresivamente, el recuerdo de los objetos de la vida cotidiana que rodeaban a la pareja va cambiando de signo y da paso a imágenes pesadillescas. Si una vez muerta "los espejos no olvidaban su imagen, los guantes no perdían el molde de sus manos, había almohadas que conservaban el hueco formado por su cabeza (...)" (161), luego, esa ausencia se sustituye por la amenaza de la amada muerta en la referida versión fatal.

La estructura de la narración diferencia claramente este pasaje, en donde el narrador apela con mayor énfasis al destinatario-amigo de la carta: "Pero es al llegar aquí cuando comienza lo más negro, lo que, siempre egoísta, me preocupa más de todo este drama. No te rías" (161). El personaje masculino cree que la muerta, en su variante de "leona iracunda", ha regresado para vengar su odio. La supuesta amenaza de la suicida perturba a tal grado la vida del narrador alucinado, que éste teme perder la razón. Las señales del regreso fantasmal femenino se acumulan, motivo por el cual el narrador pide con desesperación ayuda a su viejo amigo.

A pesar de ser una amenaza, después de muerta, la amada se transforma en el objeto de deseo cada vez más preciado: los recuerdos de aquel amor ideal; la morbidez del cuerpo femenino y la delicadeza de sus gestos permanecen como recuerdos vívidos en la imaginación del narrador, rememorando a la mujer en su versión frágil, aunque con tintes necrofílicos. Al respecto, en "Una obsesión" se describe en una de las escenas la contemplación del narrador de la amada muerta en su féretro, uno de los temas que según Poe es lo más bello que la literatura puede mostrar. ${ }^{4}$ En Filosofía de la Composición (1846) Edgar Allan Poe señaló que "the death, then, of a beautiful woman is, unquestionably, the most poetical topic in the World -and equally is it beyond doubt that the lips best suited for such topic are those of a bereaved lovern. ${ }^{5} \mathrm{El}$ protagonista, de la misma manera que la voz narrativa del poema "The Raven", ("El cuervo") se encuentra alterado por la separación definitiva de la amada. ${ }^{6}$

Otra temática frecuentada por las narraciones de Edgar Allan Poe y compartida por "Una obsesión", es la de la mujer que regresa de la tumba para visitar a su amor (o primer amor), como en el cuento "Ligeia", en donde la primera esposa retorna del sepulcro y destruye a la nueva amante del narrador. Incluso, este último, para huir del círculo vicioso de temor que le inspira el regreso de la muerta, piensa en volver a casarse, tal como sucede en la trama de "Ligeia"; sin embargo, desiste de la idea, ya que tiene la certeza de que la presencia fantasmal no desaparecerá. Sin embargo, a diferencia de "Ligeia", el inmenso saber y erudición de la primera esposa y su paridad con el poeta son antitéticos respecto del vínculo de subordinación y bestialización entre la ingenua Julia y el refinado artista de "Una obsesión", como lo analizamos más arriba.

Los vínculos intertextuales no se reducen a una coincidencia temática. En la crítica que efectúa Poe de "The Hollow of the Three Hills" ("El barranco de las tres colinas") de 
Nathaniel Hawthorne, en "Hawthorne y la teoría del efecto en el cuento", el bostoniano valora la construcción del efecto de evocación fantástica a través de la utilización del oído y no de la vista (Pacheco y Barrera Linares, 1993: 306-307). Este recurso se reitera en "Una obsesión" para generar el pavor en el narrador ante la inminencia de la aparición fantasmática de la muerta:

nunca ni por nada me hubiera atrevido a escribir esto de noche, temeroso de sentir el golpe en el hombro o sus pasos avanzando silenciosos con precaución (...). No estoy loco, no, pero la siento errando invisible a mi alrededor, el sonido quejumbroso de una puerta al ser empujada por el viento...(es por el viento?) me ha hecho estremecer (...). (161)

El procedimiento valorizado por Poe se vincula con otros dos señalados por Rosemary Jackson: la elisión y la sustitución. La investigadora ha señalado que el fantasy "no presenta escenas como si fueran reales: insiste en la realidad de la transformación" (1986:8485). Respecto de esta afirmación, el narrador de "Una obsesión" teme encontrarse con el retorno del cuerpo de Julia y ese recelo se plasma en los dos procedimientos recién señalados: la elisión y la sustitución (1986:85). El narrador sustituye el nombre propio de la amada por el sonido de su cuerpo y elide, de esa manera, toda referencialidad.

El relato tiene un final abierto, ya que permite suponer que la carta jamás abandonó la casa y, por lo tanto, el narrador alucinado no logró escapar del acecho de la muerta. En este punto, advertimos una resignificación de Couto Castillo respecto del suicidio de la amada. Durante el siglo xix, estar enferma se consideraba un signo de delicadeza de espíritu y de clase, y el arte intervino en la celebración del culto a la tísica sublime, como explica Bram Dijkstra (1986:29). Sin embargo, la invalidez no era más que la expresión simbólica de un prejuicio: la incapacidad femenina para ser por sí misma, ya que sin la ayuda del hombre se la consideraba un ser incompleto, perdido. El recurso al suicidio era una vía que podía considerarse natural. El mismo acto de autodestrucción fue visto como una elección lógica de la heroína virtuosa o de la que, gracias a él, se redimía y lograba serlo. En "Una obsesión", Julia se suicida ya que no será la Amada del narrador, sino una entre tantas. Los prerrafaelistas y otros pintores británicos y alemanes empezaron a buscar en las leyendas ejemplos con los cuales describir el desvarío en que caían aquellas que no eran amadas. Su camino era la desesperación primero y la autodestrucción después, ya que su vida carecía de sentido. Heroínas como Lady of Shalott, de John William Waterhouse; Ofelia, el personaje trágico de Shakespeare y otras como Elaine, Isabella, Matelda... fueron las protagonistas de muchos de los cuadros de la segunda mitad del siglo xix. ${ }^{7}$

Couto Castillo se apropia del tópico del suicidio del prerrafaelismo para mostrar la subordinación de Julia al narrador, sin embargo, al incorporar el tema de la amada que retorna de la tumba vía Poe, el mexicano recoloca a la figura femenina en el espacio de la mujer fatal, cuya presencia acosa al narrador y puede destruirlo. Asociada a la muerte, la representación femenina coutiana ataca el "signo" del personaje unificado realista y comienza a establecer una fisura en su configuración.

Con respecto a la gravitación del personaje femenino en "Una obsesión", Coral Velázquez Alvarado sostiene que éste no tiene una función propia, sino que es funcional para la caracterización insana del protagonista. La investigadora considera que Julia "es «metalenguaje», pues representa la lucha del protagonista con lo desconocido, es un símbolo cuyo significado se amplifica con la muerte" (2014:138). Si bien coincidimos en la dependencia del personaje femenino respecto de las ansiedades del protagonista, sin embargo, atendiendo a las apropiaciones y re significaciones que efectúa Couto Castillo de los elementos arriba señalados, en la narración no podría sustituirse a la fémina por ningún otro personaje del reino animal, vegetal o
7. Como ejemplo de las apropiaciones de ciertos motivos de la literatura por parte de la pintura, el prerrafaelista John Everett Millais pinta en 1852 el óleo Ofelia. 
mineral. En ese marco, el vínculo con el personaje femenino adquiere un rol central y problemático: cargado de erotismo, es el espacio de lo conocido en su versión frágil, pero también, su opuesto, cuando deja de ser quien se da más, y se convierte en quien exige y aspira a dominar, en su versión fatal. La imagen femenina invade, poco a poco, el ámbito de lo cotidiano como presencia sobrenatural, capaz de desquiciar y conducir al espacio de la locura.

\section{Calaveras y erotismo}

Un ojo abierto y otro cerrado, por un lado moza y por otro vieja, unas veces anda despacio y otras aprisa, parecía que estaba lejos y estaba cerca y cuando pensé que entraba, ya estaba en mi cabecera. Y viendo tan extraño ajuar preguntele quién era, y dijome:

- La Muerte.

Francisco de Quevedo, El sueño de la muerte

En "Celos póstumos", el protagonista posee una calavera humana como adorno en su escritorio, frente a la que ha mantenido con su amada diversas escenas amorosas. El cráneo le reclama haber sido menospreciado y exige el derecho que tuvo en vida sobre aquel cuerpo femenino, recordándole al hombre que algún día él también morirá y su lugar como amante será reemplazado por otro sujeto.

El erotismo de los cuerpos es el desencadenante de la conciencia de la mortalidad, aunque, paradójicamente, frente a una función de semejante envergadura, la fémina se represente mediante la metonimia y la fragmentación del cuerpo y tenga obturada toda posibilidad de trascendencia, ya que su destino será la reiteración, en un círculo sin fin, de la escena erótica:

sus labios, sus labios, perfumados de placer y de deseo, se posaron en los míos (...) (107). Tus dedos la han estrechado (...) y se han perdido en la cascada odorante de sus cabellos (107), sus ojos húmedos de deseo, los vi, porque harto los conocía (107). Mañana estarás muerto, y ante tu cráneo pasearán a la mujer que hoy amas. (108)

El personaje principal es un joven que busca, junto con su amada, saciar el ansia sensorial, y para ello se traslada al cementerio. En ese ámbito, "profanan" el universo de la eternidad y, entre el temor y el deseo, sienten sobre ellos la mirada de un "inmenso ojo vigilador" proveniente del mundo de los muertos. Tras esta peripecia, el protagonista retorna a su cuarto y, lleno de angustia, advierte que las cuencas vacías de la calavera se iluminan. Ante la sensación de hastío, el protagonista interroga al cráneo en pos de alguna respuesta.

Las representaciones pictóricas barrocas de las vanitas se componían de una calavera y algunas flores caídas, relojes de arena y diversas frutas, a veces en descomposición, símbolos alusivos a la temporalidad de la vida. Fernando R. de la Flor argumenta que este tipo de representaciones escapan a la figuración realista, perspectiva desde la que habían sido estudiadas por investigadores que veían en ellas un catálogo de objetos para su conocimiento exhibicionista en los espacios de recepción burguesa. Son, en cambio, para de la Flor, "idealizaciones y cosmovisiones simbólicas" (2002:87), "creación misteriosa y parlante (...) de un dios que se esconde, cuyo mensaje es el de advertir del carácter pasajero y efímero del propio mundo" (2002:89). El investigador retoma a Philippe Ariès, quien señala que

la vanitas respondería a un proceso de capilarización de la idea de muerte y de lo efímero en el espacio social. Lo que en la Baja Edad Media se exhibía en la intimidad 
de los templos, como producto de un ars moriendi, casi en exclusiva reservado para los clérigos, salta en la Edad Moderna incluso al espacio decorativo y a los gabinetes y claustros de las elites intelectuales. (Ariès, 2002: 89, n. 25)

El fantástico decadente se diferencia del fantástico tradicional en el cambio de decorado: mientras que el segundo elegía preferentemente el marco del aislamiento del campo para la aparición de lo insólito, el cuento fantástico decadente se desarrolla en la vida moderna, en el universo urbano. Estas transformaciones alcanzan a la aparición de la idea de la muerte que, en sintonía con la explicación de Ariès, en "Celos póstumos" se cuela en el cuarto secularizado del protagonista. En la narración, el cráneo no está acompañado de ninguno de los elementos que lo rodeaban en las representaciones pictóricas de las vanitas; sin embargo, estos se suplen a través de la palabra: en "Celos póstumos" el cráneo habla y compone una vanitas discursiva. La calavera le reclama al protagonista la profanación del descanso de los muertos y el robo de la mujer que fuera suya. La escena remite al memento mori en donde el joven recibe las palabras del cráneo, que le recuerda que la muerte llegará para él y para su amada, igualando a todos los mortales.

¡Insensato!, no solo robas a los muertos lo que fue suyo, sino que también vas a su morada, a su morada que debía ser de paz, y turbas su silencio con tus frases y haces estremecerse lo que en ellos queda de vida con tus besos, ostentando ante sus pobres restos tu juventud y tu descaro (...). (107)

Yo la inquietaba, ¡oh!, jsí!, lo pertinaz de mi mirada sin ojos la inquietaba, lo pertinaz de la mirada en que tantas veces se vio!, jah! No pensaba que tal vez su cráneo luciría algún día sobre una mesa; que dentro de sí lleva el esqueleto que le causa espanto y que algún día, desnudo como el mío, dormirá a solas en estrecha cama, teniendo por único calor el del gusano, y por única blancura las tablas húmedas de un medio podrido ataúd! (107)

Las recriminaciones del cráneo provocan en el joven amante gran conmoción y como consecuencia, lo llevan a arrojar la calavera, que se rompe en mil pedazos. Por una parte, la narración favorece la línea de lectura de que el narrador-protagonista actuó de esa manera debido a la angustia que le provocó la conciencia de la mortalidad. Sumado a ello, existe otra línea de análisis que involucra el deseo, ya que después de haber hecho añicos el cráneo, el narrador no tiene paz y no puede volver a besar a su amada.

Para analizar el tratamiento del deseo en el fantasy, Rosemary Jackson recurre a las interpretaciones de Leo Bersani. Según el investigador, en muchos textos del siglo xix se elaboran problemas de interacción social y represión del deseo. Las novelas tienden a encerrar este dentro de estructuras centradas alrededor de la familia, que se produce y se sostiene a sí misma mediante tabúes contra impulsos libidinales. En este período, el fantasy trajo a la superficie los deseos inconscientes y amenazó con disolver esos tabúes. Bersani ejemplifica con La piel de zapa de Balzac. En la narración, el héroe, Raphael, puede realizar todos sus deseos a través de una piel mágica. Pero la satisfacción de cada deseo hace que la piel se encoja y que se acorte el tiempo de vida del personaje. Pauline, su amante, le causa la muerte precisamente por el deseo que siente por él. Al respecto, Jackson concluye que "la elección de Raphael representa alegóricamente un conflicto que aparece en muchos fantasy del siglo xix, cuando irrumpen y chocan con las formas realistas: la elección del deseo sin la vida, o de la vida sin deseo" (Jackson, 1986: 134).

Es posible comparar las operaciones señaladas en La piel de zapa con aquellas desplegadas en "Celos póstumos". En el comienzo, los amantes satisfacen sus deseos 
amatorios y desafían a la muerte. Sin embargo, luego de la intervención de la calavera parlante, el camino del narrador protagonista es la vida sin deseo, ya que no puede besar a la mujer, y su destino gira en torno al temor a morir y, una vez sin vida, el pavor a quedar expuesto a la visión del deseo en los cuerpos de los otros. De ahí que podemos concluir que en "Celos póstumos", los tópicos barrocos de la vanitas y el memento mori son refuncionalizados para dar cabida al discurso del deseo, que fluye a través de la ficción.

Como se analizó en este artículo, el tríptico narrador alucinado, mujer y muerte adopta diferentes configuraciones en "Una obsesión" y en "Celos póstumos", todas ellas leídas desde el fantasy. Sin embargo, más allá de sus particularidades, en ambas ficciones se advierte un fluido diálogo con la tradición literaria y pictórica, en la que la figura de Edgar Allan Poe ocupa un espacio central. Asimismo, en ambas narraciones, el discurso del deseo adopta diferentes ropajes, revisitados y, en algunos casos, reformulados por Couto Castillo. Las resignificaciones analizadas se focalizaron en el funcionamiento de la vanitas en "Celos póstumos" y en la reorientación de la concepción del suicidio en el prerrafaelismo, a partir de la introducción del motivo dilecto de Poe de la amada muerta que retorna a la vida, en "Una obsesión". En ese marco, la presencia femenina, aunque carezca de voz, con su presencia ataca el "signo" del personaje unificado, aspecto que tiene sensibles consecuencias en términos de cuestionamiento al proceso de construcción de ambos relatos. 


\section{Bibliografía}

» Bachelard, G. (1992). “El cajón, los cofres y los armarios”. En La poética del espacio. México, Fondo de Cultura Económica, pp. 107-123.

"Cervantes, M. (2011). “Estudio preliminar”. María Cervantes (Selección). Asfódelos y otros cuentos. Antología crítica. Bernardo Couto Castillo. Rosario, Serapis, pp. 7-78.

"Colombi, B. (2013). "Rubén Darío y el mito de Poe en la Literatura Hispanoamericana”. En Rocío Oviedo Pérez de Tudela (editora), Rubén Darío en su laberinto. Madrid, Verbum, pp. 223-237.

»Couto Castillo, B. (1987). “Una obsesión”. En Revista Moderna. Arte y ciencia, (1898-1903), año 4, núm. 10, 2ª quincena de mayo, 159-161. México, UNAM.

»Couto Castillo, B. (1987) “Celos Póstumos”. En Revista Moderna. Arte y ciencia, (1898-1903). México, Universidad Nacional Autónoma de México, vols. I-II. Edición Facsimilar, Año I, 7, 1º de noviembre de 1989, pp. 107-108.

"Couto Castillo, B. (1897). “Cuentos criminales. Blanco y rojo”. En El Mundo Ilustrado, t. I, núm. 12, 21 de marzo de 1897, p. 186.

»Chartier, R. (1996). "El mundo del texto y el mundo del lector: la construcción del sentido". En El mundo como representación. Barcelona, Gedisa, pp. 50-53.

»Chaves, J. (2013). "Couto, a la sombra de Dios”. En México heterodoxo. Diversidad religiosa en las artes del siglo xix y comienzos del xx. México, Bonilla Artigas Editores, pp.149-153.

»Dijkstra, B. (1986). "El culto a la invalidez; Ofelia y la locura; mujeres muertas y el fetiche del sueño". En Ídolos de la perversidad. La imagen de la mujer en la cultura de fin de siglo. Barcelona, Debate, pp. 25-63.

» Jackson, R. (1986). Fantasy. Literatura y subversión. Buenos Aires, Catálogos.

»Pacheco, C y Barrera Linares, L. (Comp.) (1993). Del cuento y sus alrededores. Aproximaciones a una teoría del cuento. Caracas, Monte Ávila Editores.

»Pierrot, J. (1977).L'imaginaire decadent (1880-1900). Paris, Presses Universitaires de France.

»Poe, E. A. (1990). “El demonio de la perversidad”, en Cuentos. Buenos Aires, Alianza, pp.185-192. Traducción de Julio Cortázar.

»Poe, E. A. The Philosophy of Composition. Recuperado de http://www.eapoe.org/ works/essays/philcomp.htm>.

"Poe, E. A. (1992). "Hawthorne y la teoría del efecto en el cuento", en Del cuento y sus alrededores. Aproximaciones a una teoría del cuento. Venezuela, Monte Ávila, pp. 295-309.

"Quirarte, V. (2001). “Cuerpo, fantasma y paraíso artificial”, en Literatura mexicana del otro fin de siglo. México, El Colegio de México, pp. 19-33.

» R. de la Flor, F. (2002). “Negro, nada, infinito. Vanitas y cuadros metafísicos en la pintura del Siglo de Oro”, en Barroco. Representación e ideología en el mundo hispánico (1580-1680). Madrid, Cátedra, pp. 76-121.

" Tablada, J. J. (1889). “El monstruo”, en Revista Moderna, año 2, núm.4, Abril, p. 102. 
»Velázquez Alvarado, C. (2014). “Estudio Preliminar”, en Obra reunida. Bernardo Couto Castillo. México, UNAM, 2014, pp. 53-16o.

"Zavala Díaz, A.L. (2012). “De la muerte y sus metáforas: Bernardo Couto CastiIlo", en De Asfódelos y otras flores del mal mexicanas. Reflexiones sobre el cuento modernista de tendencia decadente (1893-1903). México, UNAM, pp.131-143. 